\title{
Not So Fast, Mr. Pinker: A Behaviorist LoOks at The Blank Slate. A ReView Of Steven Pinker's The Blank SLATE: THE MODERN DENIAL OF HUMAN NATURE
}

\author{
2002, New York: Viking. ISBN 0670031518. 528 pp. \$27.95.
}

Stephen Pinker's latest book, The Blank Slate: The Modern Denial of Human Nature, is getting a lot of press. But Pinker's claims of human nature hinge in large part on providing evidence of its "modern denial." Toward that end he singles out behavioral psychology as one of the purveyors of the blank slate position. If the book is judged on how accurately he makes the case, then it doesn't fare too well.

First of all, those interested in how well Pinker succeeds in making his argument for human nature are encouraged to read behavioral biologist Patrick Bateson's scathing review in Science (September, 2002). Bateson takes Pinker to task for reviving the "wearisome" nature-nurture debate and writes that, "Saloonbar assertions do not lead to the balanced discussion that should be generated on a topic as important as this one." Bateson even questions the central assumption of Pinker's title, namely that human nature is still routinely denied. And he cautions that all examples of behaviors that benefit individuals in the modern world are not necessarily products of evolution. As numerous scientists have pointed out, patterns of behavior that seem to be adaptive may be so because they were selected in our evolutionary history or in individuals' own lifetimes by learning experiences. Bateson also accuses Pinker of simplistic assumptions regarding the role of genes in determining behavior.

But the criticisms of Pinker's book can and should go beyond even that. For my part, I want to concentrate on Pinker's treatment of behavioral psychology and its two most notable spokespersons, John B. Watson and B. F. Skinner.

\section{PINKER's POLITICS}

To begin with, it should be noted that although Pinker is a skilled writer, the writing in this book is often sensational and combative and certainly not modest. For example, he writes that his book can "offer a touchstone by which we can identify suffering and oppression ... unmasking the rationalizations of the powerful." It is in this context that the reader encounters behaviorism and Watson and Skinner.

Pinker writes that, "It's not just behaviorists and Stalinists who forgot that a denial of human nature may have costs in freedom and happiness" (p. 177). Elsewhere, he refers to B. F. Skinner as "ever the Maoist ..." and compares some of Skinner's ideas to those inherent in totalitarian fascist and communist systems. Pinker cites Skinner's biggest detractor, Noam Chomsky, when he writes that, "no

one doubts that behavior can be controlled, putting a gun to someone's head or threatening him with torture are time-honored techniques" (p. 169). 
These are the words of a polemicist. It's is incongruous for Pinker to assert the objectivity of science and then associate Stalin, Mao, totalitarianism, and torture with an American psychologist who because of his contributions to improving the lives of so many, was given the International Award of the Joseph P. Kennedy, Jr. Foundation for Mental Retardation in 1971 and the Humanist of the Year Award from the American Humanist Society in 1972.

Behaviorists (nowadays called behavior analysts) have for decades successfully helped children with various learning and behavior problems to lead happier, more fulfilled lives. Does Pinker really mean to imply that, for example, children with autism, many of whom have literally been saved from horrible lives of institutionalization by programs of applied behavior analysis which grew directly out of the work of Skinner and others, are being oppressed by those who help them? Is applied behavior analysis totalitarianism in the guise of genuine service?

As Bateson (2002) notes, Pinker's "misplaced combative style" does a disservice to his own goals, not to mention the good work of others. In any case, although Pinker claims his book is not political, many of the topics addressed are not scientific but highly charged philosophical and political issues. Words like "Stalinists," "Marxists," and "totalitarianism" are emotionally laden political terms that do not serve any scientific point Pinker wants to make.

Pinker has obviously got an ax to grind. His slant on these issues is infused with personal, ad hominem attacks on others. The irony is that a look at Pinker's curriculum vitae (see http://www.mit.edu/ pinker/cv.html) reveals no experimental work that is relevant to this topic. Compare that to B. F. Skinner's corpus of experimental work on basic learning principles that provided the foundation for thousands of experiments by hundreds of others over the past 70 years. That work, in turn, has expanded into a general scientific theory of behavior, and spawned numerous therapeutic and educational applications that have helped thousands of people all over the world. Such achievements earned Skinner the National Medal of Science in 1968 and the first American Psychological Association Citation for Outstanding Lifetime Contribution to Psychology in 1991.

\section{PINKER's FACTS}

Worst of all, Pinker is simply wrong about the positions of many of those he accuses as blank slate advocates, especially John B. Watson and B. F. Skinner. If Pinker were to report their works accurately, he would find positions that recognized innate tendencies and traits or, in his words, "human nature." For example, John Watson's book, Behaviorism, has an entire chapter on instinct and his forgivably naive interpretation of emotion recognized some basic innate ones. Nevertheless, Pinker trots out Watson's famous "Give me a dozen healthy infants ..." quotation in the first few pages of his book introducing it as "one of the century's most famous pronouncements of the Blank Slate." It isn't until one hundred pages later, buried within a paragraph that Pinker alludes in the briefest way to the next line of Watson's statement: "I am going beyond my facts and I 
admit it, but so have advocates of the contrary and they have been doing it for many thousands of years." By "the contrary," Watson meant those who at the turn of the century and afterwards promoted hereditary explanations of intelligence, using their non-scientific racial theories to carry out their own forms of oppression. In fact, one could easily make the opposite case of Pinker: that those who have stressed human nature in the form of hereditarian theories, have been responsible for numerous and documented forms of oppression and tyranny.

In the Blank Slate, Pinker, like Watson, is reacting to "those who have argued to the contrary" - or at least those he paints as arguing to the contrary. The difference is that Watson knew he was going beyond his facts; Pinker unabashedly sticks to his even though they have been seriously questioned (e.g., Schlinger, 1996).

Regarding Skinner, Pinker is especially harsh. In addition to calling him a Maoist, Pinker misrepresents Skinner's position on several issues and gets his facts wrong on several others. Because of Pinker's status, one cannot help but conclude that he must understand Skinner's theory, but intentionally misstates it to bolster his own position. For example, Pinker writes that Skinner's first book, The Behavior of Organisms, dealt only with rats and pigeons lever-pressing and keypecking, implying that we couldn't possibly learn much about humans from such species.

First off, Skinner's book did not report any experiments with pigeons. But more importantly, Pinker seems not to have read Skinner's statement early in the book that "In the broadest sense a science of behavior should be concerned with all kinds of organisms, but it is reasonable to limit oneself, at least in the beginning, to a single representative example. Through a certain anthropocentricity of interests we are likely to choose an organism as similar to man as is consistent with experimental convenience and control" (1938, p. 47). Is this not the strategy of all experimental scientists - to simplify in the beginning?

For Pinker to imply that rats (or pigeons) are in no way representative of human beings is to ignore one of Darwin's seminal concepts-species continuity. After all, we take medications initially tested on other animals such as laboratory mice, and have no problem with species continuity in that regard. And many neuroscientists interested in the human brain use rats in their research. Finally, the operant principles first elucidated by Skinner in The Behavior of Organisms have been extensively documented with humans.

Predictably, Pinker next mentions the work of the Brelands who in their attempts to train animals discovered the "instinctive drift" of certain behaviors. Pinker uses this to "remind psychologists that species and their instincts mattered after all." I know of no behaviorist who ever ignored the species characteristics of laboratory subjects. On the contrary, such things are taken into account when deciding on a particular species. And Pinker fails to mention that the Brelands remained committed behaviorists until their deaths and their successors continue to carry out successful animal training to this day. More importantly, animal training has become more humane in part because of Skinner's decades-long emphasis on using positive reinforcement rather than aversive measures to condition behavior. 
As a result the lives of numerous animals, including those who in turn help humans such as seeing-eye dogs, have been improved.

In his effort to again associate Skinner with control and oppression, Pinker writes that "Skinner's preferred method of operant conditioning required starving the organism to $80 \%$ percent of its free-feeding weight and confining it to a box .. . " (p. 169). The words "starving" and "confining" are unfortunate and are more evidence of Pinker's combative style. Perhaps Pinker doesn't know that animals in the wild are rarely, if ever, at their free-feeding weight; the only animals who are at free-feeding weights are some pets and laboratory animals (Poling, Nickel, \& Alling, 1990). So, depriving them to $80 \%$ of their free-feeding weight is not starving them, but getting them to a more normal, free-ranging weight.

Pinker also misunderstands Skinner's position on the role of the brain on behavior when he writes, "As late as 1974, Skinner wrote that studying the brain was just another misguided quest to find the causes of behavior inside the organism rather than out in the world" (p. 20). I could not find in Skinner's 1974 book, About Behaviorism, any statement by Skinner that resembled Pinker's paraphrase. But no matter. Skinner never discounted the proper role of physiology in behavior; he discussed it in numerous articles and books. His position was simply that the ultimate causes of behavior are located in an organism's individual history and in the species' evolutionary history, not in the brain.

\section{Pinker's CARicature OF BeHAVIORISM}

Pinker's portrayal of behaviorism is, to use Bateson's (2002) term, a "caricature." Pinker dredges up many of the clichéd objections to behaviorism that other critics have offered over the years. For example, he writes that Watson "banned talents or abilities from psychology together with other contents of the mind such as ideas, beliefs, desires and feelings ..." because behaviorists were only interested in overt behavior.

Such characterizations are unfortunate because they are wrong. In numerous places, Skinner and countless other behaviorists have stated quite clearly that behavior is any thing an organism does, including public (overt) as well as private (covert) actions. The behaviorist, like the molecular biologist or astrophysicist, assumes that, for the most part, unobservable events obey the same laws as the observable ones they can study.

Pinker tells us that behaviorism is dead. But there are currently thousands of active practicing behaviorists all over the world with numerous scientific journals and dozens of professional organizations, including a division of the American Psychological Association. And if one includes basic researchers, for example, comparative psychologists and neuroscientists who study the effects of environmental variables on behavior and the brain, as well as cognitive behavior therapists, the numbers swell. Obviously, Pinker's report of the death of behaviorism is not just greatly exaggerated, it is wrong.

If these characterizations hadn't been rebutted so often by behaviorists themselves and so prominently, such as by Skinner in About Behaviorism, as well 
as by numerous others in articles, including those in the flagship journal of the American Psychological Association, the American Psychologist (see, for example, Todd \& Morris, 1992), then such scholarship might be excusable. However, in this case, Pinker's poor scholarship is indefensible. Of course, if Pinker had done his homework and reported the behaviorist position accurately, he could not have used it as a primary example of a blank slate position that denies human nature.

If the above is any indication, the scholarship in the Blank Slate is less than exemplary and probably represents a case where personal ambition has clouded objectivity. In the examples I've described, Pinker engaged in less than adequate scholarship, misrepresentation or misunderstanding of, and unnecessary personal attacks on, those with whom he disagrees. Such strategies might sell books, but in the long run they do not serve objective science.

\author{
Henry D. Schlinger ${ }^{1}$ \\ California State University
}

\title{
REFERENCES
}

Bateson, P. (September 2002). The Corpse of a Wearisome Debate. Science, 297 (27), 2212-2213.

Pinker, S. (2002). The Blank Slate: The Modern Denial of Human Nature. New York: Viking.

Poling, A., Nickel, M., \& Alling, K. (1990). Free birds aren't fat: Weight gain in captured wild pigeons maintained under laboratory conditions. Journal of the Experimental Analysis of Behavior, 53, 423-424.

Schlinger, H. D. (1996). What's wrong with evolutionary explanations of human behavior. Behavior and Social Issues, 6, 35-54.

Skinner, B. F. (1938). The Behavior of Organisms. Englewood Cliffs, N.J.: Prentice-Hall.

Skinner, B. F. (1974). About Behaviorism. New York: Knopf

Todd, J. T., \& Morris, E. K. (1992). Case histories in the great power of steady misrepresentation. American Psychologist, 47, 1441-1453.

\footnotetext{
${ }^{1}$ Correspondence concerning this review should be addressed to the author at: Department of Psychology, California State University, Northridge, Northridge, CA 91330-8255, or by email to hschling@csun.edu.
} 